\title{
Kohti hyvää aikuisuutta
}

\section{"Omilleen asettumisen" kulttuurinen kuva}

\author{
JATTA HERRANEN \& PÄIVI HARINEN
}

\begin{abstract}
Tarkastelemme artikkelissa aikuisuuden siirtymävaihetta - tai niin sanottua kehkeytyvää aikuisuutta - nuorten suomalaisten aikuiseksi kasvamiselle ja itsenäistymiselle antamia merkityksiä ja sisältöjä. Kehkeytyvä aikuisuus käsitteenä viittaa yleensä 18-29-vuotiaiden elämänvaiheeseen, jota esimerkiksi Jeffrey Jensen Arnett (2000; 2004) luonnehtii identiteetin etsimisen, epävakauden, minäkeskeisyyden, välissä olemisen ja mahdollisuuksien iäksi.
\end{abstract}

\begin{abstract}
Varhaisista riippuvuussuhteista irtautuminen ja itsenäistyminen ovat aikuistumiskeskustelun kestosisältöjä. Itsenäistymisen vaatimus sisältyy erityisesti elämänkulkuamme ohjaaviin kehityspsykologisiin vaiheteorioihin, joissa puhutaan muun muassa aikuisuuden siirtymäjaksosta ja siihen kiinnittyvistä kehitystehtävistä. Kehityspsykologiset teoriat ovat olleet normatiivisesti vahvoja ja siirtyneet sujuvasti osaksi kulttuurisia hyvän elämän määrityksiä ja odotuksia jälkimodernissa yhteiskunnassa, jossa niistä on tullut yhdessä koettua ja jaettua sosiaalista, kulttuurista ja yksilökohtaista todellisuutta.

Pureudumme tässä artikkelissa erityisesti lapsuuden kodista irrottautumiseen keskeisenä kehkeytyvän aikuisuuden yhteiskunnallisena velvoitteena, opetettuna ja opittuna representaatiopakotteena. Artikkeli perustuu kahdeksan nuoren parissa tehtyihin ryhmähaastatteluihin sekä eläytymismenetelmän keinoin koottuun kirjoitelma-aineistoon $(n=28)$. Irtiotto lapsuuden oloista ja tiloista näyttäytyy aineistossamme sisäistettynä, aikuistuvia yhdistävänä ja sosiaaliseksi paineeksi koettuna normina, joka on täytettävä erilleen asettumiseen liittyvän yksinäisyyden mahdollisuuden uhallakin. Jos tätä normia syystä tai toisesta ei kyetä noudattamaan, syntyy kulttuurista jännitettä, ja seurauksena on yleensä paikoilleen jämähtämisen, häpeän ja elämässä epäonnistumisen kulttuurisia elämäntarinoita.
\end{abstract}

Kehityspsykologiset aikuistumisen teoriat ja näkemykset jälkimodernin yhteiskunnan luonteesta asettuvat keskinäiseen sopusointuun ja ruokkivat toisiaan; jälkimoderni on vahvojen aikuisten kypsä tila (vrt. Eräranta 2007). Jälkimoderni yhteiskunta on itsestään ja jäsenistään tietoinen, itsensä kanssa keskusteleva ja refleksiivinen (esim. Beck 1995). Refleksiivisyyden kulttuuri läpäisee yhteiskunnan makro- ja mikromaailman ja tunkeutuu yksilöiden elämänkulkuun erilaisina tiedostamisen, valtautumisen, autonomisuuden, sosiaalisen aktiivisuuden ja oikeiden valintojen ideologiana. Ideaalielämänkulun ja -sosialisaation näkökulmasta refleksiivisyyteen kasvanut yksilö päätyy lopulta hallittuun olotilaan, jota luonnehtivat itsenäisyys ja "omillaan pärjääminen”.

Suomalaisessa keskustelussa omillaan pärjäämättömyyttä on luonnehdittu muun muassa riippuvuuden käsitteellä. Yksilön vahvuutta korostavassa kulttuurissa riippuvuus on jopa patologisoitu - aikuistumisen ongelmista puhuessamme puhumme esimerkiksi pitkittyneestä nuoruudesta, ”peräkamarin pojista”, lapsissaan roikkuvista vanhemmista ja "sairaista" (läheis)riippuvuussuhteista. Lapsuuden oloihin ja ympäristöön jämähtäminen on kulttuurisesti häpeällistä ja stigmatisoivaa individualisoituneessa yhteiskunnassa, joka odottaa autonomista yksin selviytyjää. Riippuvuuden ja häpeän liitolla on Suomessa Yhdysvaltojen ja Britannian tapaan hegemoninen asema (ks. esim. Sennett 2004).

Suomessa, kuten muissakin Pohjoismaissa, itsenäistymisen ideaali on sidottu vahvasti lapsuudenkodista irrottautumiseen (ks. esim. Aapola \& Ketokivi 2005; Holdsworth \& Morgan 2005). Irtautumisen ideaalin tuleminen todeksi näkyy esi- 
merkiksi asumistilastoissa: vuonna 2005 suomalaisista 25-vuotiaista nuorista aikuisista enää kymmenen prosenttia asui vanhempiensa tai muun huoltajan luona, kun alle 20-vuotiaista asui 80 prosenttia (Nuorista Suomessa 2006). Nuoret miehet näyttävät kärsivän naisia enemmän ”itsenäistymishäiriöistä”, koska heidän osuutensa kotona asuvista on huomattavasti suurempi kuin nuorten naisten (Myllyniemi 2005). Itsenäistymisen ideaalin ja todellisuuden kulttuurista luonnetta voi hahmottaa vertaamalla "vielä kotona" asuvien suomalaisnuorten määrää esimerkiksi maahanmuuttajatutkimuksiin, joiden mukaan ei-suomalaisten nuorten kotoa irtautumisella ei ole niin voimakasta kulttuurista kiirettä (esim. Paananen 2005).

Kehityspsykologisten teorioiden mukaan itsenäistymismuutossa konkretisoituvassa irrottautumisessa ei ole kysymys vain osoitteen muutoksesta, vaan monimutkaisesta elämänvaiheeseen (ei kronologiseen ikään sinänsä) kiinnittyvästä prosessista, jonka päämääränä on aikuiseksi tuleminen. Sen katsotaan edellyttävän yksilöltä tietoista pohdintaa ja neuvottelua sekä oman minän ja aikuisuuden maailman vaatimusten yhteensovittamista (ks. Levinson 1978, 72-78). Hyvän elämän normiksi määritettyyn itsenäistymiseen osana yhteiskunnallisesti hyvää aikuisuutta ja oman elämän osallisuutta sisällytetään kotoa irtautumisen ja pois muuttamisen ohella myös muita aikuisuuteen sidottuja elämänhallinnallisia kehitystehtäviä, kuten uusien läheisten ihmissuhteiden rakentamista, ajattelun avartumista sekä toiminnallisen vapauden ja toimintakyvyn kehittymistä (Kosonen 2005, 122; Arnett 2004).

Myötäillessään, tuottaessaan ja ylläpitäessään individuaatioideologiaa kehityspsykologien määrittämä kypsä aikuisuus on kulttuurisesti hyvää ja tavoiteltavaksi asetettua aikuisuutta (Herranen \& Harinen 2007). Nuorten asumista tutkinut Marko Raitanen (2001) väittääkin, että esimerkiksi luonnollisena asiana pidettyä irtiottoa vanhemmista ja lapsuuden ympäristöistä eivät ohjaa sisäiset tekijät, vaan nuoren asema yhteiskunnassa ja yhteiskunnan luonne yleisemmin. Irtiotot voi siis tulkita myös merkeiksi kulttuurisesti oikeaan suuntaan etenevästä elämästä, ja autonomian tavoittelu on ymmärrettävissä osoitukseksi sitoutumisesta jälkimodernin yhteiskunnan vaatimuksiin ja ehtoihin - oman elämän suhteuttamiseksi niihin (vrt. Bourdieu \& Wacquant 1995; Giddens 1991). Omilleen pyrkivä on oppinut kulttuurin kirjoittamattomat säännöt ja sisäistänyt elämän normatiivisen käsikirjoituksen (Herranen \& Harinen emt.).

\section{Kiinnostuksen kohteina kulttuuriset merkitykset}

Tässä artikkelissa hyödynnettävä ryhmähaastatteluaineisto kerättiin helmikuussa 2006 osana humanistisella ja kasvatusalalla opiskelevien ammattikorkeakouluopiskelijoiden opintoja. Haastattelun kahdeksasta nuoresta aikuisesta seitsämän oli naisia. Haastattelut tehtiin neljän henkilön pienryhmissä, joissa keskusteltiin 45-55 minuuttia omaa elämää ohjanneista valinnoista oheisten kysymysten siivittäminä: Minkälaisia valintoja olet tehnyt elämäsi aikana? Mitkä asiat ovat ohjanneet kyseisten valintojen tekemistä? Miten perhe, koulu, vapaa-aika, kaverit (vertaiset), media ja työ ovat vaikuttaneet valintoihin?

Ryhmähaastattelun kysymykset pohjautuivat oletukseen siitä, että nuorten elämään liittyy paljon erilaisia elämänpoliittisia valintatilanteita. Käytännössä ryhmähaastatteluissa keskusteltiin pääosin koulutusvalinnoista ja kotoa irtautumisesta, joissa molemmissa sekä van-

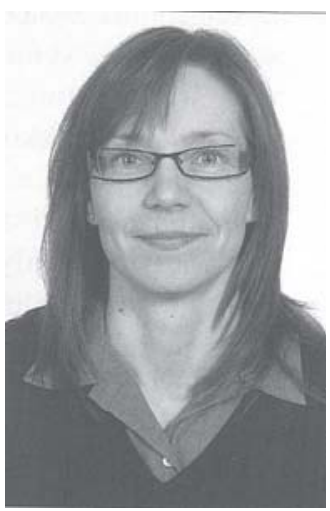

Jatta Herranen

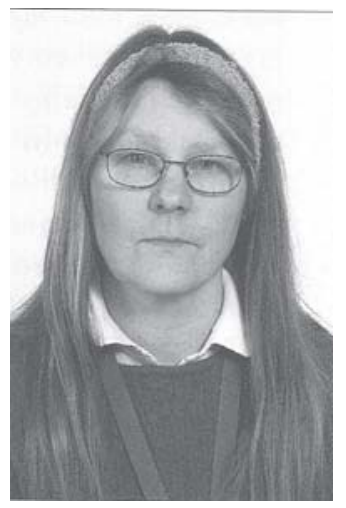

Päivi Harinen hemmat että vertaiset ovat olleet tärkeitä neuvottelukumppaneita. (Herranen \& Harinen 2007).

Aineiston toinen osa, eläytymismenetelmäaineisto, kerättiin toukokuussa 2007 myös osana humanistisella ja kasvatusalalla opiskelevien ammattikorkeakouluopiskelijoiden opintoja. Eläytymismenetelmän keinoin tuotettuja kirjoitelmia on yhteensä 28, joista viisi on miesten kirjoittamia. Tutkimukseen osallistuneista opiskelijoista puolet laati tarinansa oheisen kehyskertomuksen pohjalta: Olet 24-vuotias nuori ja olet muuttanut pois lapsuudenkodistasi. Eläydy tähän tilanteeseen ja kerro, millainen on elämäntilanteesi ja mitkä asiat ovat vaikuttaneet siihen, ettet asu vanhempiesi 
luona. Loput rakensivat tarinansa seuraavan kehyskertomuksen perusteella: Olet 24-vuotias nuori ja asut vanhempiesi luona. Eläydy tähän tilanteeseen ja kerro, millainen on elämäntilanteesi ja mitkä asiat ovat vaikuttaneet siihen, että asut lapsuudenkodissasi. Eläytymismenetelmän instruktio laadittiin siten, että toisessa kehyskertomuksessa esitettiin tietoisesti yleinen itsenäistymistä symbolisoiva aikuistumiseen liittyvä normi ja toisessa rikottiin se. Tämä provosoiva asetelma pakotti tutkimukseen osallistuneet ottamaan kantaa, mahdollisesti puolustautumaan ja luomaan yleisesti hyväksyttyjä selityksiä.

Aineiston analyysissa olemme irtautuneet eläytymismenetelmän systemaattisia eroja etsivästä periaatteesta ja tarkastelleet molempia aineistoja yhtenä kokonaisuutena, siitä tulkittavissa olevien merkitysteemojen puitteissa. Ryhmähaastattelut ja eläytymismenetelmätarinat soveltuvat hyvin kulttuurisia merkityksiä ja tapoja konstruoivaan analyysiin, koska niiden tapana on tuottaa konventioita, sovinnaisuuksia, kompromisseja ja yleisiä näkemyksiä. Ryhmähaastattelun keinoin olemme jäljittäneet nuorten aikuisten tekemien elämänpoliittisten valintojen sosiaalisia kiinnikkeitä ja niiden normatiivista voimaa. Yhdessä keskustelemalla olemme tehneet näkyviksi nuoren aikuisen elämää ohjaavia normeja ja ihanteita (ks. esim. Eskola \& Suoranta 2005, 95; myös Suurpää 1996). Eläytymismenetelmän avulla olemme pyrkineet keräämään kotoa poismuuttoon - yhteen ryhmähaastatteluissa tärkeäksi osoittautuneeseen elämänpoliittiseen valintaan - sidottuja ja jaettuja kulttuurisia merkityksiä, mikä on tarjonnut mahdollisuuden tarkastella kehkeytyvään aikuisuuteen liittyviä itsestäänselvyyksiä (ks. esim. Eskola \& Suoranta mt., 116-117; Peräkylä 1999, 44). Sekä haastattelu- että kirjoitelma-aineistossa yhdistyvät yksilön kokemukset ja kulttuurinen diskurssi; niissä tuotetaan jaettuja representaatioita ja suodatetaan uniikkeja kokemuksia, jotka yhdessä kietoutuvat asioille annetuiksi neuvotelluiksi merkityksiksi (esim. Alasuutari 2001, 72; Moilanen \& Räihä 2001, 46-47; Peräkylä mt.).

Analyysimme pohjana oleva empiirinen aineisto on valikoitua, koska se on koottu korkeakoulutuksessa olevilta nuorilta ihmisiltä, jotka ovat kulttuurisesti hyväksytyssä suunnassa matkalla kohti täysvaltaista aikuisuuttaan. Tällaisesta positiosta muunlaiset elämäntilanteet näyttäytyvät helposti ongelmaisina, mikä lienee vaikuttanut aineiston luonteeseen. Aineisto on vinoa myös siinä mielessä, että kaikkineen tutkimukseen osallistui 30 nuorta naista ja kuusi nuorta miestä. Yksilöllistymistä korostavan kulttuurin ja individuaatiokehityksen on jostain syystä katsottu olevan edullisempaa naisille kuin miehille (Saresma 2005, 60-61), mutta tässä analyysissa sukupuoliulottuvuutta ei voi tarkastella johtopäätöksiksi asti.

Seuraavassa tarkastelemme keskeisiä aineistossamme läsnä olevia merkitysteemoja: kotoa irtautumisen kulttuurista painetta ja "kotiin jämähtämisen” häpeällisyyttä ja puolustelutarvetta, itsemääräämisen ja yksityisyyden ihannetta sekä yksinäisyyttä hintana, joka ollaan valmiita maksamaan aikuistumisen kulttuurisen tehtävän täyttämiseksi. Olemme erottaneet suorat aineistolainaukset muusta tekstistä joko kursivoinnein tai sisennyksin. Tekstistä irrotettujen lainausten lopussa olevat koodit viittaavat joko haastattelun [H1-2] tai eläytymistarinan [T1-30] järjestysnumeroon. Tekstin luettavuuden vuoksi kappaleiden sisällä olevat kursivoidut aineistolainaukset on jätetty koodaamatta. Ilmaus "kotona asuminen" viittaa tekstissä lapsuuden kodissa asumiseen.

\section{Riippumattomuuden lunastaminen ja vapauden viehätys}

Erityisesti suomalaisessa yhteiskunnassa omillaan pärjääminen on keskeinen hyvän elämän normi ja kulttuurinen mittari (esim. Mononen 2007; Mikkola 2005). Suomalaisessa aikuistumiskeskustelussa itsenäistyminen onkin palautunut sekä mentaaliseen että fyysiseen irtiottoon yksilöllisyyttä kahlehtivista riippuvuuksista, joista lapsuuden perhettä pidetään keskeisimpänä. Lapsuuden perheestä irrottautuminen on kulttuurissamme määrittynyt itsestään selvästi tavoiteltavaksi asiaksi (ks. esim. Salonen 2005; Raitanen 2001). Oikea-aikainen irtautuminen lapsuuden perheestä konkretisoituu kotoa poismuuttamisena. Se on aikuistuvan yksilön velvollisuus, jolla hän osoittaa riippumattomuutensa ja halunsa itsenäistyä, aikuistua ja aloittaa oma aikuinen elämä.

Ei liene sattumaa, että ryhmähaastatteluihin osallistuneet noin 20-vuotiaat pitävät kotoa poismuuttamista yhtenä merkittävimmistä elämäänsä ohjanneista elämänpoliittisista valinnoista. Nuoret haastateltavamme ovat oppineet, että tapahtuu jotain tärkeää, kun muutat kotoa pois ja alotat itsenäisen elämän. Kotoa poismuutto on välttämätön eronteko matkalla aikuisuuteen, joten se on 
vaan joskus otettava se askel (vrt. Aapola 2005, 272). Kehkeytyvän aikuisen on aika päästää irti vanhemmista ja alkaa kantaa vastuuta omasta elämästä. Käytännössä hänen täytyy ryhtyä rakentamaan omaa juttua. Ryhmähaastatteluihin osallistuneiden nuorten mielestä alaikäisen asemasta vapautumiseksi - riippumattomuuden saavuttamiseksi - on olennaista, että ihanteena pidettyyn itsenäiseen elämään kottoo on aina kannustettu (...) ja ne [vanhemmat] ei itkeny mun perrään että et lähe minnekään. Ne on tienny sen, että joskus se on tehtävä.

Kotoa irtautuminen on myös yksi itsestään huolehtivaa kunnon aikuiskansalaisuutta määrittävä tekijä. Nuoren aikuisen ei ole sopivaa olla toisten elätettävänä. Hänen on uskallettava kokeilla omia siipiään heti toisen asteen koulutuksen päätyttyä ja osoitettava näin kykynsä elää vanhemmistaan riippumatonta elämää.

No mää nostin heti kytkintä lakkiaisten jälkeen. Olisin mää voinu jäähä kotiin samalle paikkakunnalle ja ilmakseks asuu ja saaha ruuvat pöytään samalla lailla, mutta mää kituutin sillä työmarkkinatuella. Kyllähän ne porukat tuki sitten. Mä olin ekana lähössä Helsinkiin mun kaverin kanssa. Siinä ne sano sitten, että siihe ei heru rahaa, että jos sinne lähet, että ei siinä oo mitään järkee. Ei siinä oliskaan ollu mitään järkee. Tuli vaan sellanen olo, että vois lähtee. [H1]

Nuorta yksilöä velvoittavan oikea-aikaisen irrottautumisen ohella lapsuuden kodista muuttaminen on irtiotto perheestä sekä emotionaalisessa että materiaalisessa mielessä. Lapsuuden oloista irtautumisen pohtiminen tuotti tutkimusaineistoomme paljon perheen rooliasemiin liittyvää tarkastelua ja merkityksenantoa. Perhe merkitsee yleensä vahvoja sosiaalisia siteitä, jotka eivät salli tai mahdollista anonyymisyyttä, yksinoloa ja vain itselle tai henkilökohtaisille ystäville elämistä. Perhesidokset eivät perustu valituille suhteille, ja vahvat sosiaaliset pakkositeet estävät tai ainakin jarruttavat aikuisille tyypillisten omaehtoisten suhteiden muodostumista.

Perheyhteisöllisyyden pakkoluonteen uskotaan tuskastuttavan erityisesti tämän ajan nuoria koulutettuja tai koulutushaluisia ihmisiä (Florida 2002, 274-277; ks. myös Jokinen 2005, 19). Vain lapsuuden siteiden katkaiseminen avaa ovia uusille, omille ja itse solmituille tuttavuuksille. Perhesiteiden kahleista vapautuminen vahvistaa nuo- relle aikuisille tyypillisenä pidetyn itsemääräämisen: Voin kutsua kavereita kylään miettimättä häiritsenkö. Voin tulla ja mennä miten haluan. Tätä analyysia varten koottu kirjoitelma-aineisto sisältää runsaasti "kyttäävien” perhesiteiden ja autonomiaa konnotoivien kaverisuhteiden vastakkainasettelua. Liian tietoisuuden toisen asioista ja siihen liittyvän jatkuvan tilivelvollisena olemisen katsotaan riistävän nuorelta yksilöltä oikeuden aikuiselle ominaisena pidetyn oman elämän elämiseen (vrt. Harinen 2000). Riippumattomuuden saavuttamiseksi tutkimukseemme osallistuneille nuorille on tärkeää, ettei tarvitse tehdä toimintaselontekoa kenellekään ja että voi toimia vapaasti ilman "isoveli valvoo" -oloa ja pelkoa kyttäyksestä.

Perheen sosiaalinen maailma on hierarkkinen, ja sen toimintakenttä perustuu yleensä vanhempien autoritäärisyyteen. Kodeista tuleekin helposti monenlaisia taistelukenttiä (vrt. Jokinen 2005, 2122). Riippumattomuuden lunastaminen merkitsee henkilökohtaista ja kulttuurista pesäeroa taakse jätettäviin auktoriteetteihin ja perheen rooliasemiin. Perhesiteissä valta ei aina näy suorana pakottamisena ja uhkailuna, vaan sen katsotaan kätkeytyvän myös monenlaisiin manipuloiviin käytäntöihin ja vetoamisiin. Seuraava lainaus erään nuoren kirjoitelmasta kertoo, kuinka kehkeytyvä aikuinen voi joutua kamppailemaan irtautuakseen sekä emotionaalisesta että materiaalisesta manipulaatiosta kasvaakseen subjektiksi, joka on siirtynyt relationaalisesta tilasta autonomiseen olemiseen (vrt. Saresma 2005, 70).

\section{Äitini pyrki kontrolloimaan elämääni ja pää- töksiäni antamalla rahaa. Hän sanoi, että olen hänelle velkaa sen, että haen yliopistoon, kos- ka hän on tukenut minua rahallisesti. Jahka- sin huonopalkkaisessa työssä kolme vuotta ja hain joka kevät yliopistoon. (En päässyt, kos- ka voimat eivät riittäneet lukemiseen työn ohella.) Lopulta päätin hakea opiskelemaan toiselle paikkakunnalle ja se oli elämäni paras ratkaisu. Ensimmäistä kertaa elämässäni tun- sin olevani lähes vapaa vanhemmistani. [T26]}

Perhesiteitä luonnehtii myös erityinen konfliktialttius, joka ei useinkaan ole läsnä esimerkiksi löyhissä kaverisuhteissa (ks. esim. Saresma 2005, 65). Kotoa lähteminen voi määrittyä harkituksi kannanotoksi konflikteihin. Perhesuhteita kalvavat ristiriidat eivät välttämättä katkea nuoren muuttaessa kotoaan, mutta välimatkan uskotaan lieventävän 
niitä. Aikuistumiseen kiinnitetty yksityisyys tai erillisyys määrittyykin nuorten kuvauksissa usein konfliktiherkkiä perhesuhteita tasapainottavaksi voimaksi ja viisauden lähteeksi (vrt. Kangasniemi 2005, 253).

Lukion jälkeen muutin pois kotoa. Ensimmäiset pari vuotta olivat hieman nihkeitä. Tykkäsin asua poissa kotoa, mutta olihan siinä omat pulmansa. Vanhempien kanssa oli riitaa \& epäymmärrystä. Mutta nyt kun äitini on hyväksynyt, etten ole enää hänen täyden valvontansa alainen, asiat ovat hyvin. Minäkään en enää yritä päteä \& olla yli-itsenäinen. [T28]

Perhesiteistä vapautumisen ohella aikuisuuteen astuminen sisältää monenlaisiin omiin tiloihin siirtymisiä ja niiden kaipuita. Tutkimusaineistossamme tilaan viitataan oman asunnon tarkkaan laskettuina neliöpinta-aloina, itse valittuina ja hankittuina esineinä, rauhan ja ristiriidattomuuden tunteina, omina salaisuuksina ja yksityisyytenä. Yksityisyys suhteessa tilaan ja sosiaaliseen merkitsee mahdollisuutta säädellä omaa saavutettavuutta (ks. Mikkola 2005, 129), mutta sisäänpäin kääntyneessä perhe-elämässä säätely ei ota onnistuakseen. Usein vasta pois lähteminen mahdollistaa sen, että nuori aikuinen pääsee itse määrittelemään sosiaalisen elämänsä rajat. Konkreettinen tila ja mentaalinen tila limittyvät toisiinsa, ja niille, jotka syystä tai toisesta ovat vastoin omaa tahtoaan joutuneet jäämään lapsuuden kotiinsa, talon läpi kulkeminen on katseiden edestä kulkemista, kontrolliin ja aneluun alistumista. Omassa tilassa on mahdollista päästä irti vanhempien velvoittavista katseista ja kontrollista, mikä synnyttää vahvoja vapauden ja riemun tunteita ja mahdollistaa aikuisille tyypillisenä pidetyn itsensä toteuttamisen.

Asun äidin ja isän kanssa, elämä menee samoilla raiteillaan kuin lapsena. Omaa elämää ei juurikaan ole, koska kuljen läpi talon omaan soppeeni. Kotona olo ahdistaa tietyin väliajoin. Omaa autoa ei ole, jonka vuoksi olen vanhempieni auton lainausluvan varassa. [T12]

Nyt asiaa pohdittuani olisin varmaankin muuttanut ihan mielelläni pois jo aiemmin [kuin 20-vuotiaana], jotta olisin voinut aloittaa oman itsenäistymiseni. Ensimmäiset viikot omassa kodissa $\left(17,5 m^{2}\right.$ yksiö) olivat mahtavat. Itsenäistymiseni tuntui kivalta, ja oli hienoa kun ei tarvinnut selitellä tekemisiään ke- nellekään. [T27]

Muuten oma koti ja oma rauha ovat olleet juuri sitä, mitä sen kuvittelinkin olevan. Oma avain, oma sänky, omat astiat, oma TV... [T25]

Irtioton materiaalisia ehtoja pohtiessaan nuoret aikuiset liikkuvat vapauden, oman tilan ja riippuvuuden välimaastossa. Ilman omia tuloja on vaikea irtautua riippuvuuksista ja muuttua autonomiseksi yksilöksi (vrt. Jokinen 2005, 27), ja kehkeytyvässä aikuisuudessa joutuu joskus tekemään kompromisseja ja vastaanottamaan "ansiotonta” tukea. Pyrkimys on kuitenkin päästä eroon riippuvuuteen viittaavista kompromisseista. Aineistossamme esiintyvät maininnat esimerkiksi työn ja opiskelun yhdistämisestä tuottavat kuvaa vastuullisesta ja kykenevästä aikuisuuden harjoittelijasta ja ikään kuin kaksinkertaistavat autonomiavakuuttelua. Huomionarvoista on, että tutkimukseemme osallistuneet nuoret aikuiset eivät korosta palkkatyötä vieroksuvaa boheemielämää, jonka joissakin tutkimuksissa on havaittu olevan tämän päivän nuorille oman tiensä etsijöille erityisen ominaista (Sell 2007).

Eritellessään lapsuuden kotiin jäämisen tai sieltä muuttamisen taustoja nuoret aikuiset nojautuvat myös psykokulttuurin keinoihin (ks. Kivivuori 1992) ja kiinnittävät lapsuuden oloista irrottautumiseen kasvuun, henkiseen kehittymiseen ja erityisesti itsevarmuuteen liittyviä ehtoja ja syitä. Aikuiseksi kasvavan on kyettävä osoittamaan riippumattomuuteensa sekä itselleen että muille.

Muuttamiseeni vaikuttaa myös se, että haluan näyttää perheelleni sekä lähimmäisilleni, että tulen toimeen omillani ja osaan pitää huolta itsestäni. (...) [T23]

\section{Riippuvuuden häpeä ja legitimaatio}

Nuorten aikuisten ajatukset omasta, itse hallitusta tilasta eivät kiinnity ainoastaan vapauden, itsellisyyden ja omien rajojen asettamisen hurmioon ja subjektiivisiin kasvun kokemuksiin. Lapsuudenkodista irrottautumiseen liittyy paljon myös yhteiskunnallisen velvollisuuden täyttämisen representaatioita ja vihjauksia riippuvuuden ja häpeän kulttuuriseen liittoon yksilösankaruutta korostavassa yhteiskunnassa (esim. Sennett 2004). Sekä psykologisissa (esim. Malinen 2003) että sosiologisissa (esim. Goffman 1984) analyyseissa häpeän kokemus kytketään ulkopuolelta tulevien odotus- 
ten täyttämättömyyteen. Häpeä on tunne ja tila, joka leimaa "viallisen”, standardiin ja odotuksiin vastaamattoman - yleisönsä pettäneen (ks. myös Harinen 2001). Myös sosiaalipsykologit puhuvat häpeästä suhteena yhteisössä vallitseviin sääntöihin ja sosiaalisen tunnustuksen puuttumisen aiheuttamana kohtalona (Moscovici 2005, 209).

Tarkastelumme pohjana olevat aineistot osoittavat aikuiseksi kasvamiseen kiinnittyvät kulttuuriset toimintakoodit ja niiden noudattamatta jättämisen herättämän epätäydellisyyden mielikuvan. Mikäli 24-vuotias asuu kotona, kyseessä on norminvastainen tilanne, josta on tehtävä tiliä, ja muutama tutkimukseemme osallistunut nuori halusikin katsella irrottautumisen normia kulttuurisen välimatkan päästä:

Kun tarkastelen asiaa länsimaalaisesta näkökulmasta, olo on hieman häviäjä. Ikää on jo reippaasti rapiat kaksikymmentä eikä omaa taloutta vielä ole. Kaverit voi kuittailla. Suku katsoo kummissaan. Peräkammarin poika. Sosiaalinen kuolema?... Toisaalta mitä kummaa siinä on jos asunkin vielä kotona? Damn, niin ne tekee monissa muissakin maissa ja vielä ylpeilee sillä. Ehkä se onkin tämä meidän yhteiskunta, jonka näkökanta asiaan on liian kapea. Kuka tietää? Mutta valitettavan usein se on juuri yhteiskunta, joka päättää mikä on kulloinkin "oikein” ja "normaalia”. Koita siinä nyt sitten tapella vastaan. [T7]

Pitkään lapsuudenkodissa asuminen tuottaa yksilölle häpeää, sillä yleensä se [kotoa pois muutto] tehtäis alle kaksikymppisenä. ${ }^{1}$ Eläytymismenetelmän keinoin tuotetuissa tarinoissa kotona asuvat 24-vuotiaat kärsivät huonosta omastatunnosta ja pitävät tilannettaan säälittävänä ja nolottavana. Kehyskertomus tuotti lukuisia kurjuuden kulttuurisia tarinoita masentuneisuudesta, heikkouden tunteista, koulunkäyntiongelmista, työttömyydestä, tulevaisuudettomuudesta ja sosiaalisten suhteiden solmimisvaikeuksista, mikä kertoo, että kotoa irtautumattomuus kytketään osaksi monisyistä ongelmavyyhteä². Lapsuudenkodista poismuuton toteutuminen LOPULTAKIN kehystetään tarinoissa helpotuksen tunteilla ja sovinnolla maailman ja itsen kanssa. Riippuvuudesta vapautuva nousee nöyryytyksen, stigman, häpeän ja arvostelun yläpuolelle. Itsellisenä hän voi uskottavasti ja sen enempiä perustelematta osoittaa pätevänsä ja pärjäävänsä.

Häpeä on sosiaalisesti herätelty emootio (Har- ré 1986), ja sen alkuperä on moraalinen. Häpeä leimaa, merkitsee, kahlitsee, rajoittaa ja pysäyttää. Myös tutkimukseemme osallistuneet nuoret aikuiset kytkevät riippuvuuteen liitettyyn häpeään pysähtyneisyyden, paikoilleen jäämisen ja taantumisen määritteitä. Lapsuuden kotiin jääminen määrittyy epäonnistumiseksi, koska elämässä on edettävä eteenpäin, lineaarisesti kuvattavissa olevalla tavalla. Kotona asuminen on kulttuuristen rajapyykkien kieltämistä (vrt. Moscovici 2005, 211), ja sen voi perustella vakuuttavasti vain väliaikaisena pakkoratkaisuna. Jos sopivaa perustelua ei löydy, kotiin jäämisen tarinoiden rivien väliin kirjoittautuu viestejä epätavallisesta heikkoudesta ja haparoivasta elämänotteesta:

Olen asunut vanhempieni luona nyt jo 24 vuotta. Olen yrittänyt muuttaa pois omaan asuntoon jo pitkään, mutta se ei ole vain onnistunut... Kaikesta huolimatta olen ajatellut piakkoin ruveta etsimään tosissani omaa asuntoa. Vanhempani ovat luvanneet tukea minua siinä rahallisesti. Muutto tulee olemaan vaikea, mutta joka tapauksessa se olisi joskus edessä. [T9]

Tutkimusaineistoissamme kotoa pois muuttamisen paineet eivät palaudu vain aikuistuvan yksilön omista asioista päättämisen ja itsellisyyden "sisäsyntyisiin” pyrkimyksiin. Ne tulevat näkyviksi myös sosiaalisina vaatimuksina ja velvoitteina, jotka konkretisoituvat esimerkiksi tarinoissa kuvatuissa vertaisten ja vanhempien kommenteissa ja käyttäytymisessä. Nuori aikuinen peilaa omaa tilannettaan muiden samanikäisten elämäntilanteeseen tiedostaen, että yleensä tuohon ikään "24 vuotta" mennessä suurin osa nuorista aikuisista on muuttanut omaan kotiin. Kaverit, jotka ovat saattaneet asua jo kauan omillaan, huomauttelevat asiasta. Vihjeitä ja vahvuusodotuksia kotoa pois muuttamisen suhteen esittävät myös vanhemmat (vrt. Harinen 2000): Joskus äiti vihjailee, että minun olisi jo aika etsiä oma asunto ja opetella huolehtimaan taloudellisista asioistani. Riippuvuudesta poispyrkiminen kuvataan monelta taholta samaan suuntaan kääntyneeksi kollektiiviseksi ohjelmaksi: kun ei päässy kouluun, niin kyllä ne [vanhemmat] vähän rupes puhuu, että mitäs jos lähtisit tästä pyörimästä.

Kuvaus kotona pyörimisestä on kulttuurisesti ja retorisesti mielenkiintoinen. Pyörivä ihminen ei etene vaan kiertää kehää ja palaa aina lähtöruutuun. Pyörimään jäänyt ei löydä suuntaa, hä- 
nellä ei ole paikkaa, johon pysähtyä, ei oikealta tuntuvaa tekemistäkään. Paikallaan pyörivä ihminen on vieras ja häiritsee, on toisten tiellä. Koska hänellä ei ole omaa paikkaa, johon asettua, hän joutuu sijoittamaan itsensä reunoille, näkymättömiinkin:

Itse haluaisin kyllä olla tuohon ikään (24 vuotta) mennessä jo sen verran itsenäinen, etten enää pyörisi vanhempieni nurkissa... [T6]

Yksilön ylivertaisuutta viestivässä yhteiskunnassa ja kulttuurissa avun pyytäminen on häpeällistä ja viittaa kyvyttömyyteen ja heikkouteen (esim. Malinen 2003). Tutkimusaineistostamme on luettavissa ironisia vihjeitä, joissa vanhempien apuun tukeutumiseen kytkeytyy myös laiskuuden, laskelmoinnin ja uusavuttomuuden sivujuonteita:

Plussana on tietty jääkaappi, joka on aina täynnä sekä vuokra, jota ei ole. [T7]

Elämä on kuitenkin helpompaa täällä lapsuudenkodissa. Ei tarvitse maksaa vuokraa, vesitai sähkölaskuja eikä ruokaa. [T9]

Kotona on hyvä asua: äiti tekee ruoan valmiiksi, pyykkää ja siivoaa puolestasi. Mitään arkijuttuja ei tarvitse tehdä itse. Ei tarvitse huolehtia mistään. [T6]

Riippuvuus ei tutkimukseemme osallistuneiden nuorten tuottamissa kulttuurisissa aikuistumisen kuvissa ole kuitenkaan täysin anteeksiantamatonta ja häpeällä ympäröityä. Hyväksytty "kotona roikkuminen" tarvitsee silti hyvät perustelut, joita kotoa poismuuttaminen kulttuurisena itsestäänselvyytenä ei tarvitse. Kotona asumisen katsotaan olevan sosiaalisesti oikeutettua, mikäli yksilöllä ei ole vakituista työpaikkaa eikä koulupaikkaa, jolloin ei välttämättä ole mitään järkiperäistä syytä muuttaa pois kotoa. Asema koulutus- ja työmarkkinoiden ulkopuolella tekee riippuvuuden ymmärrettäväksi ja sallituksi. Se on mahdollista, sallittua ja jopa järkevää myös silloin, jos nuori esimerkiksi joutuu jatkamaan opintojaan kotipaikkakunnallaan.

Lapsuudenkodissa asuminen 24-vuotiaana on oikeutettua myös silloin, jos se on kaikkien perheenjäsenten kannalta mielekästä ja järkisyin perusteltua. Tällöin ei ole kyse yksilön laiskuudesta, avuttomuudesta tai toisten hyväksikäytöstä, vaan kommentit rakentuvat vastavuoroisen tuen argumenteille. Nuoret aikuiset tiedostavat, että siipeily ei ole suotavaa (ks. myös Viinamäki 1996, 64-65), mutta lapsuudenkodissa asuminen on oikeutettua, mikäli vanhemmat tarvitsevat apua ja huolenpitoa. Kehkeytyvää aikuisuutta elävät nuoret katsovat velvollisuudekseen huolehtia vanhemmistaan tilanteen niin vaatiessa ja rakentavat näin kuvaa välittämiseen perustuvasta yhdessä pysymisestä, jota psykologit ovat opettaneet nimittämään riippuvuuden terveeksi muodoksi (ks. Malinen 2003).

Isän lähdön jälkeen äiti on ollut tosi heikko ja se on varmaan kanssa syynä siihen miks mä asun vielä kotona. Eihän semmosta voi yksikään jättää, kun se ei meinaa tulla toimeen. Ovikellokin saa jo sen vauhkoksi. [T1]

\section{Riippumattomuuden hinta}

Ylenmääräisellä yksilöllistymisellä ja itsemääräämisoikeudella on kääntöpuolensa ja riippuvuushäpeän välttelyllä hintansa: itsellisyys ja omillaan pärjääminen voivat kääntyä myös yksinäisyydeksi ja turvan kaipaamisen tai sen menettämisen kokemuksiksi (ks. esim. Saresma 2005, 43, 66). Kodin kynnyksen metafora on kulttuurisesti vahva: sen ylittävä ulos menevä ottaa riskin, kun taas sisään tuleva astuu lämpöön ja turvaan. Aikuistumisen irtiotoissa on läsnä yksinäisyyden ja ajelehtimaan jäämisen uhka, joka kytketään usein juuri elämänmuutosvaiheisiin (Kangasniemi 2005, 230, 239). Kodista ulos astumiseen sisältyvä yksin jäämisen riski pohdittaa myös tutkimukseemme osallistuneita nuoria aikuisia. Itsenäistä elämäänsä aloittelevan nuoren aikuisen yksinäisyys hahmottuu kuvauksissa joko tutusta tilasta liian kaukana olemisena tai sosiaalisten kontaktien puuttumisena (vrt. Saresma emt., 101). Tämä kertoo, paitsi kodin ja perhesuhteiden myyttisestä voimasta, myös yksinolon ja yksinäisyyden kulttuurisesta vieroksuttavuudesta.

En pidä yksinäisyydestä, ja siksi kauhistuin, kun vanhempani ottavat puheeksi muuttoni omaan asuntoon. Olemme siis keskustelleet asiasta, mutta yleensä en ota puheita tosissani. [T9]

Irti repäisty tai itsensä irrottanut saattaa huomata, että joskus omaa tilaa ja aikaa, jota toisaalta kaivataan, onkin liikaa (vrt. Mikkola 2005, 137): vain yhden ihmisen hallitsema koti voi emotionaalisesti turvaton paikka. Yksinäisyys on havaitsemamme poissaolo (Taimela 2005, 188); yksinäisen elämästä puuttuu jotain. Omillaan pärjäämisestä saatu voima ja elämän ulkoisen käsikirjoituksen hal- 
linta saavat täyttymyksen vasta, kun ne voi kehystää aktiivisilla ystävyyssuhteilla ja myönteisillä sosiaalisilla kontakteilla. Samoin kuin riippuvuuteen, myös yksinäisyyteen tai yksin elämiseen kytkeytyy suoria tai epäsuoria vihjeitä epäonnistumisesta, arvottomuudesta, ulkopuolisuudesta ja emotionaalisista "vääristymistä".

Kuka tietää jäänkö lapsuudenkotiini vuokralaiseksi vai muutanko toiselle paikkakunnalle omilleni, mutta ainakin tällä hetkellä ajatus tutusta kotipesästä irtautumisesta nostaa ihoni kananlihalle ja täyttää mieleni ahdistuksella. [T10]

Vaikka yksinäisyyden uhkaa pidetään aikuistumisen ei-toivottuna lisäjuonteena, sille antautuminen on kuitenkin hinta, jonka nuori aikuinen katsoo olevansa valmis maksamaan - onhan itselliseksi siirtymisen myönteisinä pidettyjen asioiden vaakakupissa kuitenkin niin paljon hyvää ja tavoiteltavaa:

Toki on hetkiä jolloin tunnen oloni yksinäiseksi, mutta vapaus tuo kuitenkin mukanaan monia niin hienoja juttuja ja etuja, etten vaihtaisi sitä pois mistään hinnasta. [T27]

Yksinäisyys on epämiellyttävänä nähty asia, eikä sitä useinkaan tarkastella muuten kuin mahdollisimman pitkälle vältettävänä tilana ja olosuhteena. Tutkimukseemme osallistuneiden nuortenkaan esiin nostama yksinäisyys ei ole syvää ja eksistentiaalista orpouden kokemista (esim. Fromm 1941) vaan jonkinlaista tilanteittaista "välähdysyksinäisyyttä”, joka aktualisoituu tiettyinä hetkinä ja jonka kompetentti aikuistoimija voi pyyhkiä pois hakemalla seuraa omien seinien ulkopuolelta tai projisoimalla seuran- ja turvankaipuunsa lemmikkieläimiin.

Tosin ihan kiva olisi aamukahvi juoda jonkun kanssa. No mutta, onneksi meillä on kahvilakulttuuri. Oma taloudellinen tilanne ei vain salli joka-aamuista kahvilavisiittiä. Kiva on hengailla kavereiden kanssa kahviloissa, mutta aika usein joutuu tyytymään jääveteen. [T16]

Yksin asuminen houkuttelee, mutta ensimmäiseen asuntoon muuttamista helpottaisi kenties jos muuttaisi yhdessä kämppisten kanssa. Uusi paikkakunta on täysin vieras ja kämppiksistä saisi vertaistukea uudessa ympäristössä. Kenties myös joku lemmikkieläin helpottaisi sopeutumista onhan siitäkin seuraa ennen kuin pääsee tutustumaan muihin ihmisiin. [T23]

Kehkeytyvässä aikuisuudessa nähdään yksinäisyyden riski, koska muutos on suuri ja vapauden rajat ovat venyneet aiemmilta sijoiltaan. Omillaan pärjääminen käy työstä, ja tutkimusaineistossamme onkin useita kuvauksia välimatkan päähän jätetyn perheyhteyden ja avautuvan autonomian tasapainoilusta. Tätä ongelmaa ratkaisemaan löytyy kuitenkin suhteista tärkeimmäksi ja antoisimmaksi määritelty: parisuhde. Elämänkumppanin etsintä on yksi keskeisimpiä kehkeytyvälle aikuiselle annettuja yhteiskunnallisia ja kulttuurisia kehitystehtäviä, ja siitä muistuttaminen on läsnä kaikkialla kulttuurissamme. Tämän aikuistumistehtävän onnistunut täyttäminen näkyy tutkimusaineistossamme elämän harmonian, läheisyyden, tuen ja turvan ajatuksiin liitettynä. Jos "se oikea” löytyy ja parisuhde syntyy, uusi läheisyys siivoaa tieltään muut suhteet ja aikuistumiseen kiinnitetty yksinäisyysuhkakin kaikkoaa.

\section{Odotusten täyttyminen ja täyttäminen}

Ikävaiheet ovat yksilöllisillä ja sosiaalisilla odotuksilla latautuneita kategorioita ja määrittelykohteita, ja ne täyttyvät monilla yksilöä viehättävillä ja velvoittavilla representaatioilla. Elämänkulun siirtymävaiheeksi kutsuttu kehkeytyvä aikuisuuskaan ei ole vain sarja tai jatkumo yksilöllisiä päätöksiä ja kokemuksia, vaan siihen kiinnittyy paljon yhteiskunnallista ja kulttuurista vetoa, työntöä ja suunnannäyttöä (vrt. Holdsworth \& Morgan 2005, 3). Onnistuneen siirtymän ja hyvän aikuistumisen mallit ovat vahvoja normatiivisten opasteiden pystyttäjiä. Yksilön vapautumiseen nojaavan omilleen asettumisen kulttuurinen kuva on haluttava ja houkutteleva, ja sen tavoitteleminen on itsestään selvää ja hyväksyttävää. Kun nuori aikuinen määrittelee ja kokee aikuisuuteen astumisen monien odotustensa täyttymiseksi, hän samalla peilaa niitä odotuksia, joita jälkimodernissa yhteiskunnassamme on asetettu aikuisuuteen sijoitetuille. Odotuksia ja opasteita väistellen kulkevat joutuvat etsimään toiminnalleen, olosuhteilleen ja valinnoilleen - roikkumiselleen ja pyörimiselleen - sosiaalisesti kestävää oikeutusta, joka palautuu esimerkiksi marginaaliseen asemaan koulutus- ja työmarkkinoilla tai erityisvälittämiseen velvoittaviin perheolosuhteisiin.

Aikuisuus on monin odotuksin kehystetty yhteiskunnallinen tila (Koski \& Moore 2001), jota 
luonnehditaan autonomian, itsenäisyyden ja omillaan pärjäämisen ideaalein. Kehkeytyvä aikuisuus on kulttuurisesti perusteltu ja vaadittu irtiotto ja siirtymä jaettuun joskin henkilökohtaisesti koettuun merkitysmaailmaan (Herranen \& Harinen 2007). Merkitykset, joita myös tämän artikkelin pohjana olevassa tutkimusaineistossa liitetään aikuiseksi kasvamiseen (ja näin myös aikuisuuteen), kiinnittyvät vapauden, yksityisyyden, omien tilojen, itsestään huolehtimisen, oman sosiaalisen elämän säätelyn ja perhevastuiden uusjaon tematiikkoihin - kehityspsykologisten elämänvaiheoppien sisältöjä sekä niihin nojaavia jälkimodernin yhteiskunnan ideaaleja ja elämän suunnannäyttäjiä sujuvasti mukaillen.

Kehkeytyvän aikuisuuden sisällöt konkretisoituvat välimatkan otossa omiin vanhempiin ja siihen ympäristöön, jossa lapsuus ja nuoruus on eletty. Irtiotosta kieltäytyvät tai siinä epäonnistuneet määritellään pääsääntöisesti epäkypsiksi ongelmaihmisiksi, joiden matka kohti hyvää aikuisuutta on katkennut jo alkuunsa. Oikealla tavalla etenevä aikuistumisen ja irtiottojen elämänvaihe määrittyy sitä parhaillaan elävien nuorten kuvauksissa ensisijaisesti mahdollisuuksia täynnä olevaksi olemiseksi, jolloin taakse jätetyt suhteet ja olosuhteet saavat osakseen kriittistä reflektiota (vrt. Arnett 2000; 2004). Kulttuurissamme lapsuus kerrotaan yleensä onnelliseksi (Mikkola 2005, 159), mutta aikuistumisen velvoite ja sen myönteiseksi määritteleminen tuovat lapsuus- ja nuoruuskuvauksiin negatiivisia sisältöjä, joista nuorten aikuisten katsotaan haluavan päästä eroon. Arjen näkökulmasta kehkeytyvä aikuisuus määrittyykin pitkälti vapautena kodin riippuvuuksista, auktoriteettisuhteista ja luutuneista rutiineista. Jos vapautumisen lunastamiseen liittyy yksinäisyyden mahdollisuus tai riski, se ollaan valmis ottamaan, vaikkei se toivottavaksi olotilaksi määritykään.

Aikuisuuden autonomiaan kytkeytyy paljon kulttuurisesti kunniakasta ja kunniallista. Ne aikuisiän saavuttaneet, joita ei voi määritellä aikuisuuden kulttuuriseen tilaan, ympäröidään helposti epäonnistumisen, sairaalloisen riippuvuuden ja avuttomuuden ominaisuuksilla ja vihjeillä. Kehityspsykologisten teorioiden yhteiskunnallinen valta, voima ja kunnia ovat ilmeisiä: omillaan pärjäämätön, toisista riippuvainen ja autonomiaa tavoittelematon parikymppinen on jotain, jota on syytä oudoksua, vieroksua ja pitää erillään. Hänen kulttuurisesti osoitettu ja asetettu paikkansa on toisten nurkissa tai "jaloissa”, koska hän on vääränlainen ja häiritsee.

\section{Lähteet}

Aapola, Sinikka (2005). Aikuistumisen oikopolkuja? Koulutusreitit ja aikuistumisen ulottuvuudet nuorten elämässä. Teoksessa S. Aapola \& K. Ketokivi (toim.) Polkuja ja poikkeamia - Aikuisuutta etsimässä. Helsinki: Nuorisotutkimusverkosto \& Nuorisotutkimusseura ry. Julkaisuja 56, 254-283.

Aapola, Sinikka \& Ketokivi, Kaisa (2005). Johdanto: Aikuistumisen ehdot 2000-luvun yhteiskunnassa. Teoksessa S. Aapola \& K. Ketokivi (toim.) Polkuja ja poikkeamia - Aikuisuutta etsimässä. Helsinki: Nuorisotutkimusverkosto \& Nuorisotutkimusseura ry. Julkaisuja 56, 7-32.

Alasuutari, Pertti (2001). Laadullinen tutkimus. Tampere: Vastapaino. 3. uudistettu painos.

Arnett, Jeffrey Jensen (2000). Emerging adulthood. A theory of development from the late teens through the twenties. American Psychologist 55 (5), 469-480.

Arnett, Jeffrey Jensen (2004). Emerging Adulthood: The Winding Road from he Late Teens Through the Twenties. New York: Oxford University Press.

Beck, Ulrich (1995). Politiikan uudelleen keksiminen: Kohti refleksiivisen modernisaation teoriaa. Teoksessa U. Beck, A. Giddens \& S. Lash (toim.) Nykyajan jäljillä. Refleksiivinen modernisaatio. Vastapaino, 11-82.

Bourdieu, Pierre \& Wacquant, Loïc (1995). Refleksiiviseen sosiologiaan. Joensuu: Joensuu University Press.

Eräranta, Kirsi (2007) Isäksi tulossa ja tekemässä. Isäryhmät ja omaelämäkerrallinen työ isyyteen ohjaamisen välineinä. Nuorisotutkimus 1/2007, vol 25, 33-46.

Eskola, Jari \& Suoranta, Juha (2005). Johdatus laadulliseen tutkimukseen. Tampere: Vastapaino. 7. painos.

Florida, Richard (2002). The Rise of the Crea-tive Class. New York: Basic Books.

Fromm, Erich (1941). Escape from Freedom. New York: Farrar \& Rinehart.

Giddens, Anthony (1991). Structuration Theory: 
Past, Present and Future. Teoksessa C. Bryant \& D. Jary (toim.) Giddens’ Theory of Structuration. A Critical Appreciation. London: Routledge, 201-221.

Goffman, Erving (1984). Stigma: Notes on the Management of Spoiled Identity. Harmondsworth: Penguin Books.

Harinen, Päivi (2000). Valmiiseen tulleet. Tutkimus nuoruudesta, kansalaisuudesta ja kansallisuudesta. Helsinki: Nuorisotutkimusverkosto.

Harré, Rom (1986). The Social Construction of Emotions. Oxford: Blackwell.

Herranen, Jatta \& Harinen, Päivi (2007). Oikein valinneet jätetään rauhaan. Osallisuus, kulttuuri ja kontrolli. Teoksessa A. Gretschel \& T. Kiilakoski (toim.) Lasten ja nuorten kunta. Nuorisotutkimusverkosto, Nuorten osallisuus -hanke \& Humanistinen ammattikorkeakoulu. Julkaistaan 28.11.2007.

Holdsworth, Clare \& Morgan, David (2005). Transitions in Context. Leaving Home, Independence and Adulthood. Berkshire: Open University Press.

Ilmonen, Mervi, Hirvonen, Jukka \& Manninen, Rikhart (2005). Nuorten asuminen 2005. Helsinki: Ympäristöministeriö. Asunto- ja rakennusosasto. Suomen ympäristö 812. http:// www.ymparisto.fi/download.asp?con tentid=46396\&lan=fi. (Viitattu 31.7.2007.)

Jokinen, Kimmo (2005). Yksinäisyys ajan ilmiönä. Teoksessa K. Jokinen (toim.) Yksinäisten sanat. Kirjoituksia omasta tilasta, erillisyydestä ja yksinolosta. Jyväskylän yliopisto: Nykykulttuurin tutkimuskeskuksen julkaisuja 84, 9-36.

Kangasniemi, Jukka (2005). Mitä on yksinäisyys? Teoksessa K. Jokinen (toim.) Yksinäisten sanat. Kirjoituksia omasta tilasta, erillisyydestä ja yksinolosta. Jyväskylän yliopisto: Nykykulttuurin tutkimuskeskuksen julkaisuja, 227-307.

Kivivuori, Janne (1992). Psykokulttuuri: sosiologinen näkökulma arjen psykologisoitumisen prosessiin. Helsinki: Hanki ja jää.

Koski, Leena \& Moore, Erja (2001). Näkökulmia aikuisuuteen ja aikuiskasvatukseen. Aikuiskasvatus 21 (1), 4-13.

Kosonen, Pekka A. (2005). Sosiaalialan ja hoitotyön asiantuntijuuden kehitysehdot ja opiskelijavalinta. Jyväskylä studies in education, psychology and social research 271. Jyväskylän yliopisto. http://dissertations. jyu. fi/studeduc/9513922561.pdf. (Viitattu 31.7. 2007.)

Levinson, Daniel (1978). The seasons of a man's life. New York: Alfred A. Knopf.

Malinen, Ben (2003). Häpeän monet kasvot. Helsinki: Kirjapaja Oy.

Mikkola, Henna (2005). Yksinäisyyden verhi ympärillä ihmisten ohi kuljen - Yksinäisyyskertomukset Sukupolveni unta -kirjoituskilpailuaineistossa. Teoksessa K. Jokinen (toim.) Yksinäisten sanat. Kirjoituksia omasta tilasta, erillisyydestä ja yksinolosta. Jyväskylän yliopisto: Nykykulttuurin tutkimuskeskuksen julkaisuja, 129-187.

Moilanen, Pentti \& Räihä, Pekka (2001). Merkitysrakenteiden tulkinta. Teoksessa Aaltola, Juhani \& Valli, Raine (toim.) Ikkunoita tutkimusmetodeihin II. Näkökulmia aloittelevalle tutkijalle tutkimuksen teoreettisiin lähtökohtiin ja analyysimenetelmiin. Jyväskylä: Ps-kustannus, 44-67.

Mononen, Sari (2007). Yrittäjäksi jos yltäisin, oman onneni seppä jos oisin! Keskustelua yksilön vastuuttamisesta. Nuorisotutkimus 1/2007, vol. 25, 19-32.

Moscovici, Serge (2005). Häpeän ja syyllisyyden etiikka. Teoksessa Pirttilä-Backman, AnnaMaija, Ahokas, Marja, Myyry, Liisa \& Lähteenoja, Susanna (toim.) Arvot, moraali ja yhteiskunta. Sosiaalipsykologisia näkökulmia yhteiskunnan muutokseen. Helsinki: Gaudeamus, 197-215.

Myllyniemi, Sami (2005). Nuorisobarometri 2005. Teoksessa T-A. Wilska (toim.) Erilaiset ja samanlaiset. Nuorisobarometri 2005. Helsinki: Opetusministeriö, Nuorisotutkimusverkosto \& Nuorisoasiain neuvottelukunta, 12-65. http://www.minedu.fi/nuora/julkaisut/ Baro2005.pdf. (Viitattu 31.7.2007.)

Nuorista Suomessa 2006. Suomen Nuorisoyhteistyö - Allianssi. www.alli.fi

Paananen, Seppo (toim.) 2005. Maahanmuuttajien elämää Suomessa. Tilastokeskus.

Peräkylä, Anssi (1999). Vuorovaikutustutkimuksen kaksi traditiota. Sosiologia 1/1999, 4148. 
Raitanen, Marko (2001). Itsenäistyminen tietää köyhtymistä. Teoksessa T. Kuure (toim.) Aikuistumisen pullonkaulat. Nuorten elinolot vuosikirja. Nuorisotutkimusverkosto, Nuorisoasian neuvottelukunta \& Sosiaali- ja terveysalan tutkimus- ja kehittämiskeskus, 97-108.

Salonen, Reetta (2005). Milloin omaan kotiin? Aikuistumisen vastuu Suomessa ja Espanjassa. Teoksessa S. Aapola \& K. Ketokivi (toim.) Polkuja ja poikkeamia - Aikuisuutta etsimässä. Helsinki: Nuorisotutkimusverkosto \& Nuorisotutkimusseura ry. Julkaisuja 56, 66-99.

Saresma, Tuija (2005). Teen runosta rakastetun. Taideomaelämäkertojen sukupuolittuneet yksinäisyyskuvaukset. Teoksessa K. Jokinen (toim.) Yksinäisten sanat. Kirjoituksia omasta tilasta, erillisyydestä ja yksinolosta. Jyväskylän yliopisto: Nykykulttuurin tutkimuskeskuksen julkaisuja 84, 37-117.

Sell, Anna (2007). Pätkätyöttömyys ja nuorten aikuisten muuttuvat elämäntyylit. Nuorisotutkimus 1/2007, vol. 25, 3-18.

Sennett, Richard (2004). Kunnoitus eriarvoisuuden maailmassa. Tampere: Vastapaino.

Suurpää, Leena (1996). Yksilöllistä sosiaalisuutta vai sosiaalista yksilöllisyyttä? Nuorten yhteiskunnallisten identiteettien poluilla. Teoksessa L. Suurpää \& P. Aaltojärvi (toim.) Näin nuoret: näkökulmia nuoruuden kulttuureihin. Tietolipas; 143. Helsinki: Suomalaisen kirjallisuuden seura, 51-73.

Taimela, Sari (2005). Miten kirjoittaisin yksinäisyyteni? Teoksessa K. Jokinen (toim.) Yksinäisten sanat. Kirjoituksia omasta tilasta, erillisyydestä ja yksinolosta. Jyväskylän yliopisto: Nykykulttuurin tutkimuskeskuksen julkaisuja, 188-226.

Viinamäki, Leena (1996). Opiskelemaan, työhön, työttömäksi? Tutkimus nuorten itsenäistymisen ehdoista 1990-luvulla. Lapin yliopiston yhteiskuntatieteellisiä julkaisuja B. Tutkimusraportteja ja selvityksiä 23 .

\section{Viitteet}

1. Nuorten aikuisten asumista kartoittavan tutkimuksen mukaan 18-29-vuotiaiden asuminen lapsuudenkodissaan on selvästi vähentynyt viimeisten kymmenen vuoden aikana, mikä on tarkoittanut itsenäistymismuuttojen aikaistumista (Ilmonen ym. 2005).

2. Toisaalta kertomus tuotti myös jokusen tarinan siitä, kuinka kotiinpaluu elämän murjoman nuoren aikuisen elämässä voi merkitä viimeiseen pelastusrenkaaseen tarttumista: Jarmo oli 20-vuotias, kun hän muutti pois kotoa. Hän olisi halunnut muuttaa jo aikaisemmin, mutta hänen vanhempansa eivät sallineet asiaa Jarmon elämäntavan takia. Viimein vanhemmat suostuivat, sillä Jarmon oli koetettava omia siipiään. Jarmo ajautui kuitenkin kaveripiireihin, jotka olivat haitallisia hänelle. Elämä oli kokeilemista ja jatkuvien elämyksiin hakeutumista. Lopulta tämä alkoi olla haitallista Jarmon mielenterveydelle. Vanhemmat huolestuivat, sillä he näkivät Jarmon kärsimykset sekä jatkuvat velat. Jarmo syöksyi myös rikoskierteeseen. Nykyään hän on päässyt vieroitukseen, asuu vanhempiensa luona ja on löytänyt kunnollisen ja ihanan tyttöystävän. [T11]

Artikkeli saapui toimitukseen 31.7.2007. Se hyväksyttiin julkaistavaksi toimituskunnan kokouksessa 3.12.2007. 